\title{
PENGARUH BAHAN ORGANIK TERHADAP MUTU FISIOLOGIS BENIH BEBERAPA VARIETAS SORGUM (Sorghum bicolor) SETELAH MENJALANI PENYIMPANAN
}

\author{
Hixkia J. Marpaung, Eko Pramono \& M. Kamal \\ Jurusan Agroteknologi Fakultas Pertanian Universitas Lampung \\ Jl. Prof. Soemantri Brodjonegoro, No. 1, Bandar Lampung 35145 \\ E-mail:Hixkia_Marpaung@yahoo.co.id
}

\begin{abstract}
ABSTRAK
Penelitian bertujuan untuk mengetahui pengaruh pemberian dosis bahan organik yang berbeda pada mutu fisiologis benih tiga varietas sorgum.Penelitian dilaksanakan di Kebun Percobaan Balai Pengkajian Teknologi Pertanian (BPTP) Desa Negara Ratu, Kecamatan Natar Kabupaten Lampung Selatan dan Laboratorium Teknologi Benih dan Pemuliaan Tanaman, Fakultas Pertanian, Universitas Lampung pada bulan Mei 2013 sampai Maret 2014. Perlakuan disusun secara faktorial dalam Rancangan Petak Terbagi (Split plot Design) yang diulang tiga kali sebagai ulangan. Petak utama adalah dosis bahan organik dari pupuk kandang sapi (B) yang terdiri atas 0 (b0), 5 (b1), 10 (b2) dan $15 \mathrm{tha}^{-1}$ (b3) dan anak petak adalah varietas tanaman sorgum (G) yang terdiri dari varietas Numbu (g1), Keller (g2), Wray (g3). Benih yang telah dipanen dari setiap kombinasi perlakuan di uji viabilitasnya dengan metode Uji Kertas digulung (UKD). Pengujian mutu fisiologis benih dilakukan pada saat setelah panen sebelum disimpan, tiga bulan setelah disimpan, dan lima bulan disimpan. Hasil penelitian menunjukkan bahwa pemberian dosis bahan organik $15 \mathrm{tha}^{-1}$ menghasilkan mutu fisiologis benih sorgum lebih tinggi daripada tanpa bahan organik. Varietas Numbu menghasilkan benih dengan mutu fisiologis yang lebih tinggi daripada varietas Keller dan varietas Wray terutama setelah benih disimpan selama 3 dan 5 bulan. Pemberian bahan organik $15 \mathrm{t} \mathrm{ha}^{-1}$ menunjukkan peningkatan mutu fisiologis benih sorgum pada varietas Numbu dan Keller.
\end{abstract}

Kata kunci : Bahan organik, benih, mutu fisiologis, sorgum

\section{PENDAHULUAN}

Diversifikasi pangan adalah penganekaragaman komoditas tanaman pangan untuk upaya menjaga ketahanan pangan. Sorgum memiliki kandungan nutrisi dan sangat berpotensial menjadi tanaman alternatif dan kandungan nutrisi tanaman sorgum tidak jauh berbeda dengan beberapa tanaman pangan lainnya. Kadungan protein pada tanaman sorgum lebih tinggidari beberapa bahan pangan lainnya, tanaman sorgum memiliki $11 \%$ kandungan protein sedangkan jagung $9 \%$, kentang 2 $\%$, ubi kayu $1,20 \%$, ubi jalar $1,80 \%$ dan terigu $8,90 \%$. Kandungan karbohidrat tanaman sorgum lebih rendah dari beras. Kandungan karbohidrat sorgum $73 \%$ sedangkan beras 79\% (Simanjuntak, 2006).

Menurut FAO (2005), produksi tanaman sorgum berada pada peringkat ke lima setelah jagung, gandum, padi, dan jelai, produksi sorgum mencapai $59.722 .088 \mathrm{t}$ tahun $^{-1}$ Sorgum (Sorghum bicolor [L.] Moench) juga merupakan salah satu tanaman serealia yang memiliki potensi sebagai sumber karbohidrat bahan pangan. Sorgum memiliki potensi lain yang cukup luas seperti pakan ternak, bahan baku industri makanan dan minuman, bahan baku untuk media jamur merang dan industri alkohol. Potensi tersebut belum dapat tercapai karena kurangnya pemahaman terhadap tanaman sorgum, khususnya dari segi teknologi budidaya tanaman tersebut (Soeranto, 2008).

Mutu fisiologis merupakan salah satu kriteria mutu benih yang mencakup viabilitas dan ketahanan simpan benih. Mutu fisiologis benih berkaitan dengan aktivitas perkecambahan benih yang didalamnya terdapat aktivitas enzim, reaksi-reaksi biokimia serta respirasi benih. Salomao (2002) menyatakan bahwa mutu benih yang sering dijadikan ukuran adalah meliputi bentuk dan ukuran benih, daya tumbuh, vigor, serta kemurnian benih. Mutu benih sangat ditentukan faktor lingkungan danfaktor genetik. Pada penelitian ini perbedaan lingkungan dibuat dengan perlakuan bahan organik dengan dosis yang berbeda. Rany dkk., (2010) melaporkan bahwa dengan pemberian bahan organik (pupuk kandang ayam) nyata meningkatkan pertumbuhan dan hasil produksi tanaman sorgum, dan mampu meningkatkan mutu hasil produksi pada bawang merah Devi dkk., (2010). Perbedaan genetik dibuat dengan perbedaan varietas yang berbeda. Hasil penelitian sebelumnya menyatakan bahwa perbedaan varietas menghasilkan perbedaan mutu fisiologis pada 
tanaman jagung, Rahmawati dan Sania (2010) dan menurut Pramono (2010) menyatakan bahwa mutu fisiologis benih pada tanaman padi dipegaruhi oleh pemberian pupuk organik dan varietas. Hal ini menunjukkan bahwa untuk menciptakan benih sorgum yang bermutu dapat melalui perbaikan teknologi produksi. Aplikasi bahan organik dengan dosis yang tepat pada setiap varietas sorgum dapat memperbaiki pertumbuhan yangdiharapkan dapat menghasilkan benih sorgum yang berkualitas.

Tujuan penelitian adalah untuk: (1) Mengetahui dosis bahan organik yang dapat menghasilkan benih sorgum dengan mutu fisiologis tinggi, (2) Mengetahui varietas tanaman sorgum yang menghasilkan benih bermutu fisiologis tinggi, (3) Mengetahui pengaruh interaksi dosis bahan organik dan varietas tanaman sorgum terhadap mutu fisiologis benih.

\section{BAHAN DAN METODE}

Penelitian ini dilaksanakan di Kebun Percobaan Balai Pengkajian Teknologi Pertanian (BPTP) Desa Negara Ratu, Kecamatan Natar Kabupaten Lampung Selatan dan Laboratorium Benih dan Pemuliaan Tanaman, Fakultas Pertanian, Universitas Lampung pada bulan Mei 2013 sampai Maret 2014.

Percobaan ini dirancang menggunakan rancangan faktorial dengan Rancangan Petak Terbagi (Split plot Design) dalam Rancangan Kelompok Teracak Sempurna (RKTS) dengan tiga ulangan. Analisis data menggunkan uji Barlet untuk melihat homogenitas ragam antarperlakuan, uji Tukey untuk melihat aditivitas model hasil pengamatan, dan analisis ragam untuk melihat pengaruh simultan dari perlakuan. Perbedaan nilai tengah dilakukan dengan Uji Beda Nyata Jujur (BNJ). Seluruh pengujian dalam analisis data menggunakan taraf nyata $5 \%$.

Lahan seluas $836 \mathrm{~m}^{2}$ diolah sedemikian rupa sehingga baik untuk ditanami dan dipetak-petak dengan ukuran $4 \mathrm{~m} \times 4 \mathrm{~m}$, sebelum ditanam dilakukan pengaplikasian bahan organik. Penanaman dilakukan setelah dilakukan pembuatan lubang tanam dengan cara ditugal dengan jarak tanam $80 \mathrm{~cm}$ x $20 \mathrm{~cm}$. Benih yang telah dipanen, dirontokkan, dijemur di bawah sinar matahari lalu dibersihkan dari kontaminansi. Setelah kering pada kadar air $12 \%$, benih di kemas dengan kantong plastik, lalu disimpan selama 3 dan 5 bulan. benih tersebut diuji viabilitasnya sebelum dan sesudah disimpan. Uji perkecambahan dilakukan dengan media kertas merang lembab dengan metode Uji Kecambah Digulung Didirikan didalam Plastik (UKDdP). Pengamaatan dilakukan terhadap Kecepatan Perkecambahan (KP),
Persentase Kecambah Normal Total (PKNT), Persentase Kecambah Normal Kuat (PKNK), Bobot Kering Kecambah Normal (BKKN), Panjang Hipokotil (PH), Panjang Akar Primer (PAP) dan Panjang Kecambah Normal (PKN).

\section{HASIL DAN PEMBAHASAN}

\section{Hasil}

Hasil penelitian menunjukan bahwa a) pemberian bahan organik berpengaruh nyata pada mutu fisiologis benih yang ditunjukkan oleh peubah pengamatan yang diukur, pada benih sebelum dilakukan penyimpanan, setelah disimpan tiga bulan, dan setelah disimpan lima bulan, b) varietas berpengaruh nyata pada mutu fisiologis benih yang ditunjukkan oleh peubah pengamatan yang diukur, pada benih sebelum dilakukan penyimpanan, setelah disimpan tiga bulan dan setelah disimpan lima bulan, c) interaksi bahan organik dan varietas berpengaruh terhadap mutu fisiologis benih yang ditunjukkan oleh beberapa peubah pengamatan yang diukur sebelum disimpan, sesudah disimpan tiga dan lima bulan.

Benih yang berasal dari tanaman yang telah dilakukan pemberian bahan organik dapat mempertahankan mutu fisiologis benihnya setelah menjalani periode simpan selama 3 dan 5 bulan yang ditunjukkan oleh semua variabel yang memiliki perbedaan antardosis bahan organik. Pemberian bahan organik menghasilkan mutu fisiologis benih yang tinggi daripada yang tidak diberikan bahan organik meskipun telah mengalami periode simpan selama 3 dan 5 bulan (Tabel 1). Setelah mengalami periode simpan lima bulan persentase kecepatan perkecambahan pada perlakuan 0 t/ha mengalami penurunan $12,38 \%$ sedangkan perlakuan 15 tha $^{-1}$ penurunan kecepatan perkecambahan 9,4 \%. Pada persentase kecambah normal total, perlakuan 0 ton/ha mengalami penurunan $7,55 \%$ sedangkan perlakuan $15 \mathrm{t} \mathrm{ha}^{-1}$ menurun 4,67 \%. Pada persentase kecambah normal kuat menunjukkan bahwa pada perlakuan $0 \mathrm{t} / \mathrm{ha}$ mengalami penurunan $32,89 \%$ sedangkan pada perlakuan $15 \mathrm{t} \mathrm{ha}^{-1}$ menurun $18,89 \%$ (Tabel 1).

Pada saat benih sebelum menjalani periode simpan (penyimpanan 0 bulan) varietas Wray memiliki nilai tertinggi pada variabel pengamatan kecambah normal total dan kecambah normal kuat dan memiliki nilai terendah pada kecambah normal lemah. Varietas Numbu memiliki nilai tertinggi pada variabel bobot kering kecambah normal, panjang akar primer, panjang hipokotil dan panjang kecambah normal. Hal ini menunjukkan 
Tabel 1. Perbandingan nilai tengah antardosis bahan organik

\begin{tabular}{|c|c|c|c|c|c|c|c|c|}
\hline \multirow{2}{*}{$\begin{array}{l}\text { Periode } \\
\text { simpan } \\
\text { (bulan) }\end{array}$} & \multirow{2}{*}{$\begin{array}{c}\text { Dosis } \\
\text { bahan } \\
\text { organik } \\
\text { (ton/ha) }\end{array}$} & \multicolumn{7}{|c|}{ Peubah Pengamatan } \\
\hline & & $\begin{array}{c}\text { KP } \\
(\% / \text { hari })\end{array}$ & $\begin{array}{c}\text { PKNT } \\
(\%)\end{array}$ & $\begin{array}{c}\text { PKNK } \\
(\%)\end{array}$ & $\begin{array}{c}\text { BKKN } \\
(\mathrm{mg})\end{array}$ & $\begin{array}{l}\text { PAP } \\
(\mathrm{cm})\end{array}$ & $\begin{array}{l}\mathrm{PH} \\
(\mathrm{cm})\end{array}$ & $\begin{array}{l}\text { PKN } \\
(\mathrm{cm})\end{array}$ \\
\hline \multirow{7}{*}{0} & 0 & $\begin{array}{c}46,17 \\
\text { (b) }\end{array}$ & $\begin{array}{l}96,22 \\
\text { (b) }\end{array}$ & $\begin{array}{c}81,33 \\
\text { (b) }\end{array}$ & $\begin{array}{c}11,93 \\
\text { (c) }\end{array}$ & $\begin{array}{c}12,53 \\
\text { (b) }\end{array}$ & $\begin{array}{c}13,69 \\
\text { (a) }\end{array}$ & $\begin{array}{c}26,26 \\
\text { (b) }\end{array}$ \\
\hline & 5 & $\begin{array}{c}46,90 \\
\text { (b) }\end{array}$ & $\begin{array}{c}97,78 \\
(\mathrm{ab})\end{array}$ & $\begin{array}{c}83,11 \\
(\mathrm{ab})\end{array}$ & $\begin{array}{c}12,45 \\
(\mathrm{bc})\end{array}$ & $\begin{array}{c}12,61 \\
\text { (b) }\end{array}$ & $\begin{array}{c}13,74 \\
\text { (a) }\end{array}$ & $\begin{array}{c}26,19 \\
\text { (b) }\end{array}$ \\
\hline & 10 & 47,12 & 97,89 & 81,11 & 12,82 & 13,02 & 13,88 & 26,72 \\
\hline & & (ab) & $(a b)$ & (a) & (b) & (ab) & (a) & (ab) \\
\hline & 15 & 48,24 & 99,11 & 86,67 & 13,60 & 13,26 & 14,11 & 27,43 \\
\hline & & (a) & (a) & (a) & (a) & (a) & (a) & (a) \\
\hline & BNJ 0,05 & 1,18 & 2,14 & 5,03 & 0,67 & 0,54 & 1,24 & 1,16 \\
\hline \multirow{6}{*}{3} & 0 & $\begin{array}{c}37,96 \\
\text { (b) }\end{array}$ & $\begin{array}{c}88,89 \\
\text { (c) }\end{array}$ & $\begin{array}{c}60,89 \\
\text { (c) }\end{array}$ & $\begin{array}{c}10,68 \\
\text { (b) }\end{array}$ & $\begin{array}{c}11,60 \\
\text { (b) }\end{array}$ & $\begin{array}{c}11,79 \\
\text { (b) }\end{array}$ & $\begin{array}{c}23,28 \\
\text { (b) }\end{array}$ \\
\hline & 5 & $\begin{array}{c}38,74 \\
(\mathrm{ab})\end{array}$ & $\begin{array}{l}91,56 \\
\text { (b) }\end{array}$ & $\begin{array}{l}66,00 \\
\text { (b) }\end{array}$ & $\begin{array}{l}11,20 \\
\text { (b) }\end{array}$ & $\begin{array}{c}12,03 \\
(\mathrm{ab})\end{array}$ & $\begin{array}{c}12,15 \\
(\mathrm{ab})\end{array}$ & $\begin{array}{c}24,18 \\
(\mathrm{ab})\end{array}$ \\
\hline & 10 & $\begin{array}{c}40,25 \\
\text { (a) }\end{array}$ & $\begin{array}{c}93,33 \\
(\mathrm{ab})\end{array}$ & $\begin{array}{c}68,67 \\
(\mathrm{ab})\end{array}$ & $\begin{array}{c}11,24 \\
\text { (b) }\end{array}$ & $\begin{array}{c}12,43 \\
(\mathrm{ab})\end{array}$ & $\begin{array}{c}12,60 \\
(\mathrm{ab})\end{array}$ & $\begin{array}{c}25,04 \\
(\mathrm{ab})\end{array}$ \\
\hline & 15 & 40,56 & 94,00 & 72,67 & 12,30 & 12,64 & 12,93 & 25,58 \\
\hline & & (a) & (a) & (a) & (a) & (a) & (a) & (a) \\
\hline & BNJ 0,05 & 2,15 & 2,27 & 4,75 & 0,69 & 0,93 & 0,91 & 1,75 \\
\hline \multirow{5}{*}{5} & 0 & $\begin{array}{c}33,99 \\
\text { (c) }\end{array}$ & $\begin{array}{c}88,67 \\
\text { (c) }\end{array}$ & $\begin{array}{c}48,44 \\
\text { (c) }\end{array}$ & $\begin{array}{c}10,62 \\
\text { (c) }\end{array}$ & $\begin{array}{c}10,32 \\
\text { (b) }\end{array}$ & $\begin{array}{c}10,57 \\
\text { (b) }\end{array}$ & $\begin{array}{c}20,89 \\
\text { (b) }\end{array}$ \\
\hline & 5 & $\begin{array}{c}35,89 \\
\text { (b) }\end{array}$ & $\begin{array}{l}90,89 \\
\text { (b) }\end{array}$ & $\begin{array}{c}56,22 \\
\text { (b) }\end{array}$ & $\begin{array}{c}10,91 \\
(\mathrm{bc})\end{array}$ & $\begin{array}{c}10,92 \\
(\mathrm{ab})\end{array}$ & $\begin{array}{c}11,05 \\
(\mathrm{ab})\end{array}$ & $\begin{array}{c}21,98 \\
(\mathrm{ab})\end{array}$ \\
\hline & 10 & $\begin{array}{c}37,32 \\
\text { (b) }\end{array}$ & $\begin{array}{l}93,11 \\
\text { (a) }\end{array}$ & $\begin{array}{c}61,56 \\
(\mathrm{ab})\end{array}$ & $\begin{array}{c}11,41 \\
(\mathrm{ab})\end{array}$ & $\begin{array}{c}11,53 \\
\text { (a) }\end{array}$ & $\begin{array}{c}11,62 \\
\text { (a) }\end{array}$ & $\begin{array}{c}23,05 \\
\text { (a) }\end{array}$ \\
\hline & 15 & $\begin{array}{c}38,84 \\
\text { (a) }\end{array}$ & $\begin{array}{l}94,44 \\
\text { (a) }\end{array}$ & $\begin{array}{l}67,78 \\
\text { (a) }\end{array}$ & $\begin{array}{c}11,88 \\
\text { (b) }\end{array}$ & $\begin{array}{l}12,01 \\
\text { (a) }\end{array}$ & $\begin{array}{c}11,92 \\
\text { (a) }\end{array}$ & $\begin{array}{c}23,82 \\
\text { (a) }\end{array}$ \\
\hline & BNJ 0,05 & 1,48 & 2,15 & 7,17 & 0,53 & 1,12 & 0,97 & 1,97 \\
\hline
\end{tabular}

Keterangan : Nilai tengah yang diikuti oleh huruf yang sama tidak berbeda nyata berdasarkan uji BNJ pada taraf $5 \% ; \mathrm{KP}=$ kecepatan perkecambahan; $\mathrm{PKNT}=$ persentase kecambah normal total; $\mathrm{PKNK}=$ persentase kecambah normal kuat; $\mathrm{BKKN}=$ bobot kering kecambah normal; $\mathrm{PAP}=$ panjang akar primer; $\mathrm{PH}=$ panjang hipokotil; $\mathrm{PKN}=$ panjang kecambah normal.

bahwa varietas Numbu dan Wray lebih bagus dibandingkan dengan varietas Keller (Tabel 2).

Hasil penelitian menunjukkan bahwa terdapat interaksi antara pemberian bahan organik dan varietas pada persentase kecambah normal total setelah dilakukan penyimpanan selama tiga dan lima bulan. Pada interaksi ini menunjukkan bahwa pemberian bahan organik 10 dan $15 \mathrm{t} \mathrm{ha}^{-1}$ pada varietas Numbu memiliki nilai yang lebih tinggi (Tabel 3 dan 4), namun interaksi yang terlihat pada panjang akar primer menunjukkan bahwa pemberian bahan organik $15 \mathrm{t} / \mathrm{ha}$ pada varietas Numbu memiliki nilai yang tertinggi daripada interaksi yang lainnya.(Tabel 5). Kombinasi perlakuan varietas Keller dengan dosis bahan organik 10 dan $15 \mathrm{t} \mathrm{ha}^{-1}$ memiliki mutu fisiologis yang baik dengan acuan persentase kecambah normal total setelah disimpan selama 3 dan 5 bulan (Tabel 3 dan 4). Interaksi antara pemberian bahan rganik dengan varietas Wray tidak menunjukkan pengaruh yang nyata.

\section{Pembahasan}

Pemmberian bahan organik menghasilkan mutu fisiologis benih yang tinggi daripada yang tidak diberikan 
Tabel 2. Perbandingan nilai tengah antarvarietas

\begin{tabular}{|c|c|c|c|c|c|c|c|c|}
\hline \multirow{2}{*}{$\begin{array}{l}\text { Periode } \\
\text { simpan } \\
\text { (bulan) }\end{array}$} & \multirow[b]{2}{*}{ Varietas } & \multicolumn{7}{|c|}{ Peubah Pengamatan } \\
\hline & & $\begin{array}{c}\mathrm{KP} \\
(\% / \text { hari })\end{array}$ & $\begin{array}{c}\text { PKNT } \\
(\%)\end{array}$ & $\begin{array}{c}\text { PKNK } \\
(\%)\end{array}$ & $\begin{array}{c}\text { B KKN } \\
(\mathrm{mg})\end{array}$ & $\begin{array}{l}\text { PAP } \\
(\mathrm{cm})\end{array}$ & $\begin{array}{l}\mathrm{PH} \\
(\mathrm{cm})\end{array}$ & $\begin{array}{l}\text { PKN } \\
(\mathrm{cm})\end{array}$ \\
\hline \multirow{4}{*}{0} & Numbu & $\begin{array}{c}47,28 \\
\text { (a) }\end{array}$ & $\begin{array}{l}97,17 \\
\text { (b) }\end{array}$ & $\begin{array}{l}81,00 \\
\text { (b) }\end{array}$ & $\begin{array}{c}15,43 \\
\text { (a) }\end{array}$ & $\begin{array}{c}13,43 \\
\text { (a) }\end{array}$ & $\begin{array}{c}14,90 \\
\text { (a) }\end{array}$ & $\begin{array}{c}28,17 \\
\text { (a) }\end{array}$ \\
\hline & Keller & $\begin{array}{l}46,71 \\
\text { (a) }\end{array}$ & $\begin{array}{l}96,50 \\
\text { (b) }\end{array}$ & $\begin{array}{c}82,83 \\
(\mathrm{ab})\end{array}$ & $\begin{array}{c}10,95 \\
\text { (b) }\end{array}$ & $\begin{array}{l}13,05 \\
\text { (a) }\end{array}$ & $\begin{array}{c}13,67 \\
\text { (b) }\end{array}$ & $\begin{array}{l}26,76 \\
\text { (b) }\end{array}$ \\
\hline & Wray & $\begin{array}{l}47,33 \\
\text { (a) }\end{array}$ & $\begin{array}{l}99,49 \\
\text { (a) }\end{array}$ & $\begin{array}{c}85,33 \\
\text { (a) }\end{array}$ & $\begin{array}{c}11,73 \\
\text { (b) }\end{array}$ & $\begin{array}{l}12,08 \\
\text { (b) }\end{array}$ & $\begin{array}{c}13,00 \\
\text { (c) }\end{array}$ & $\begin{array}{c}24,94 \\
\text { (c) }\end{array}$ \\
\hline & BNJ 0,05 & 0,92 & 1,39 & 4,10 & 0,90 & 0,25 & 0,57 & 0,50 \\
\hline \multirow{4}{*}{3} & Numbu & $\begin{array}{c}41,53 \\
\text { (a) }\end{array}$ & $\begin{array}{l}94,00 \\
\text { (a) }\end{array}$ & $\begin{array}{l}72,50 \\
\text { (a) }\end{array}$ & $\begin{array}{c}12,75 \\
\text { (a) }\end{array}$ & $\begin{array}{c}12,53 \\
\text { (a) }\end{array}$ & $\begin{array}{c}12,72 \\
\text { (a) }\end{array}$ & $\begin{array}{c}25,25 \\
\text { (a) }\end{array}$ \\
\hline & Keller & $\begin{array}{c}37,46 \\
\text { (b) }\end{array}$ & $\begin{array}{c}90,83 \\
\text { (b) }\end{array}$ & $\begin{array}{l}62,67 \\
\text { (c) }\end{array}$ & $\begin{array}{c}10,52 \\
\text { (b) }\end{array}$ & $\begin{array}{l}12,08 \\
(\mathrm{ab})\end{array}$ & $\begin{array}{l}12,34 \\
(\mathrm{ab})\end{array}$ & $\begin{array}{c}24,42 \\
\text { (a) }\end{array}$ \\
\hline & Wray & $\begin{array}{l}39,16 \\
\text { (c) }\end{array}$ & $\begin{array}{l}91,00 \\
\text { (b) }\end{array}$ & $\begin{array}{c}66,00 \\
\text { (b) }\end{array}$ & $\begin{array}{c}10,81 \\
\text { (b) }\end{array}$ & $\begin{array}{l}11,92 \\
\text { (b) }\end{array}$ & $\begin{array}{c}12,05 \\
\text { (b) }\end{array}$ & $\begin{array}{c}23,89 \\
\text { (b) }\end{array}$ \\
\hline & BNJ 0,05 & 1,43 & 1,24 & 2,22 & 0,65 & 0,60 & 0,64 & 1,12 \\
\hline \multirow[t]{2}{*}{5} & $\begin{array}{l}\text { Keller } \\
\text { Wray }\end{array}$ & $\begin{array}{c}39,06 \\
\text { (a) } \\
33,85 \\
\text { (c) } \\
36,62 \\
\text { (b) }\end{array}$ & $\begin{array}{c}93,67 \\
\text { (a) } \\
90,50 \\
\text { (b) } \\
91,17 \\
\text { (b) }\end{array}$ & $\begin{array}{c}67,50 \\
\text { (a) } \\
53,83 \\
\text { (b) } \\
54,17 \\
\text { (b) }\end{array}$ & $\begin{array}{c}12,34 \\
\text { (a) } \\
10,64 \\
\text { (b) } \\
10,64 \\
\text { (b) }\end{array}$ & $\begin{array}{c}11,87 \\
\text { (a) } \\
10,80 \\
\text { (b) } \\
10,93 \\
\text { (b) }\end{array}$ & $\begin{array}{c}11,86 \\
\text { (a) } \\
10,88 \\
\text { (b) } \\
11,14 \\
\text { (b) }\end{array}$ & $\begin{array}{c}23,57 \\
\text { (a) } \\
21,67 \\
\text { (b) } \\
22,06 \\
\text { (b) }\end{array}$ \\
\hline & BNJ 0,05 & 0,79 & 0,86 & 3,15 & 0,63 & 0,40 & 0,35 & 0,74 \\
\hline
\end{tabular}

Keterangan : Nilai tengah yang diikuti oleh huruf yang sama tidak berbeda nyata berdasarkan uji BNJ pada taraf $5 \%$; KP = kecepatan perkecambahan; PKNT = persentase kecambah normal total; $\mathrm{PKNK}=$ persentase kecambah normal kuat; BKKN = bobot kering kecambah normal; PAP = panjang akar primer; $\mathrm{PH}=$ panjang hipokotil; $\mathrm{PKN}=$ panjang kecambah normal.

Tabel 3. Pengaruh dosis bahan organik dan varietas pada kecambah normal total setelah dilakukan penyimpanan selama tiga bulan

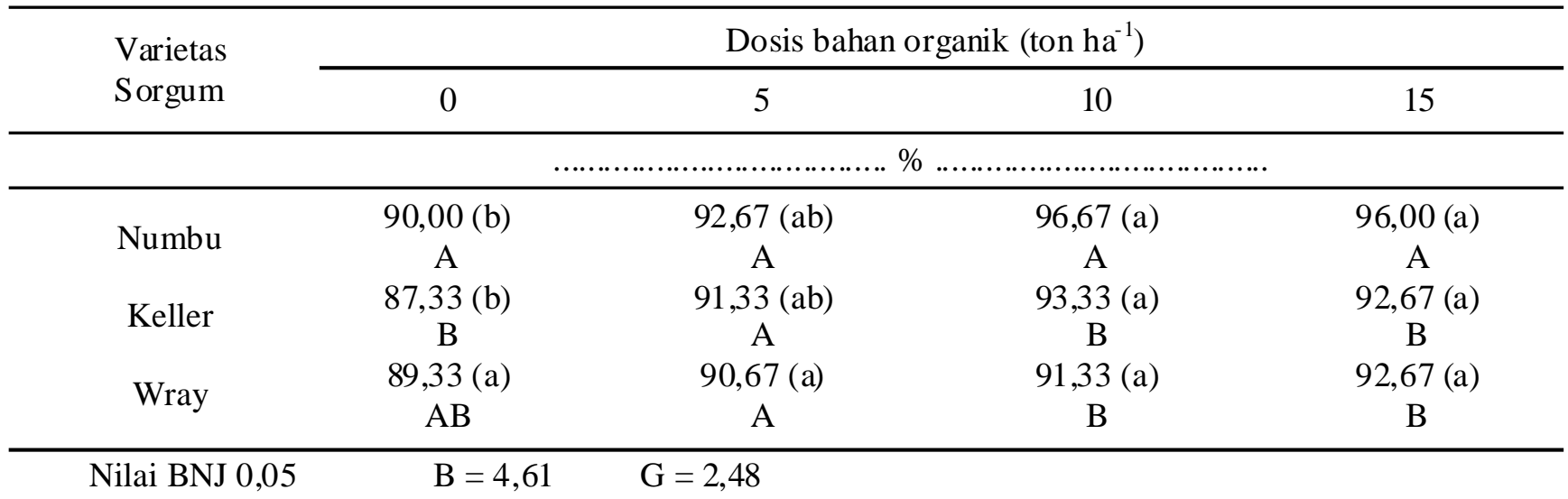

Keterangan : $\mathrm{B}=$ bahan organik, $\mathrm{G}=$ Varietas. Uji $\mathrm{BNJ}$ pada $\alpha 0,05$. Huruf kecil untuk perbandingan dalam baris dan huruf besar untuk perbandingan dalam kolom. 
Tabel 4. Pengaruh dosis bahan organik dan varietas pada kecambah normal total setelah dilakukan penyimpanan selama lima bulan

\begin{tabular}{|c|c|c|c|c|}
\hline \multirow{2}{*}{$\begin{array}{l}\text { Varietas } \\
\text { Sorgum }\end{array}$} & \multicolumn{4}{|c|}{ Dosis bahan organik (ton $\mathrm{ha}^{-1}$ ) } \\
\hline & 0 & 5 & 10 & 15 \\
\hline & \multicolumn{4}{|c|}{ 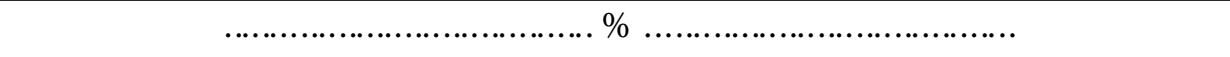 } \\
\hline \multirow{2}{*}{ Numbu } & $89,33(b)$ & $92,67(a b)$ & 96,00 (a) & 96,67 (a) \\
\hline & A & A & A & A \\
\hline \multirow{2}{*}{ Keller } & $87,33(b)$ & $89,33(a b)$ & $92,00(a)$ & 93,33 (a) \\
\hline & B & B & B & B \\
\hline \multirow{2}{*}{ Wray } & 89,33 (a) & 90,67 (a) & 91,33 (a) & 93,33 (a) \\
\hline & A & B & B & B \\
\hline
\end{tabular}

Keterangan : $\mathrm{B}=$ bahan organik, $\mathrm{G}=$ Varietas. Uji BNJ pada $\alpha 0,05$. Huruf kecil untuk perbandingan dalam baris dan huruf besar untuk perbandingan dalam kolom.

Tabel 5. Pengaruh dosis bahan organik dan varietas pada panjang akar primer setelah dilakukan penyimpanan selama lima bulan

\begin{tabular}{|c|c|c|c|c|}
\hline \multirow{2}{*}{$\begin{array}{l}\text { Varietas } \\
\text { Sorgum }\end{array}$} & \multicolumn{4}{|c|}{ Dosis bahan organik (ton ha ${ }^{-1}$ ) } \\
\hline & 0 & 5 & 10 & 15 \\
\hline & \multicolumn{4}{|c|}{ 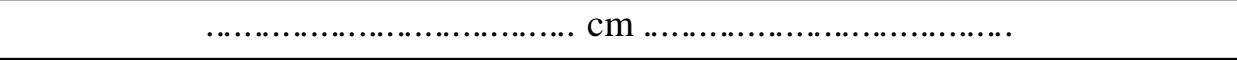 } \\
\hline \multirow{2}{*}{ Numbu } & $10,49(b)$ & $11,46(\mathrm{ab})$ & $12,54(\mathrm{ab})$ & 12,99 (a) \\
\hline & A & A & A & A \\
\hline \multirow{2}{*}{ Kell er } & 9,62 (a) & 10,77 (a) & $11,19(a)$ & $11,61(\mathrm{a})$ \\
\hline & B & B & B & B \\
\hline \multirow{2}{*}{ Wray } & $10,85(\mathrm{a})$ & 10,54 (a) & $10,87(\mathrm{a})$ & $11,44(a)$ \\
\hline & A & B & B & B \\
\hline
\end{tabular}

Keterangan : $\mathrm{B}=$ bahan organik, $\mathrm{G}=$ Varietas. $\mathrm{Uji} \mathrm{BNJ}$ pada $\alpha 0,05$. Huruf kecil untuk perbandingan dalam baris dan huruf besar untuk perbandingan dalam kolom

bahan organik meskipun telah mengalami periode simpan selama 3 dan 5 bulan. Hal ini dikarenakan pemberian bahan organik atau pupuk kompos merupakan penambahan sejumlah unsur hara kedalam tanah sebagai nutrisi tanaman. Penambahan nutrisi dan mineral yang cukup menyebabkan terjadi mobilisasi dan transport nutrisi dari bagian vegetatif ke tempat perkembangan buah, biji dan umbi sehingga nutrisi tersedia disemua bagian tanaman (Gardner dkk., 1991).

Bahan organik tidak hanya menambah unsur hara tetapi juga menjaga fungsi tanah agar unsur hara dalam tanah mudah dimanfaatkan oleh tanaman untuk menyerap unsur hara yang disediakan pupuk kimia. Penggunaan bahan organik akan meningkatkan produktivitas tanah dan mendukung pertumbuhan tanaman. Bahan organik mampu meningkatkan proses metabolisme benih yang ditunjukkan pada variabel panjang akar primer, panjang hipokotil dan panjang kecambah normal setelah penyimpanan 0,3 , dan 5 bulan (Tabel 1). Hal ini sejalan dengan pendapat Suriadikarta dkk., (2005) bahwa sumbangan bahan organik berpengaruh terhadap pertumbuhan tanaman bermula dari pengaruhnya terhadap sifat fisik, kimia dan biologitanah hingga pada mutu hasil produksi yang dihasilkan.

Pada periode simpan selama lima bulan, pemberian bahan organik dengan dosis $15 \mathrm{t} / \mathrm{ha}$ menghasilkan nilai yang tertinggi untuk variabel kecepatan perkecambahan, kecambah normal kuat, bobot kering kecambah normal. Pemberian bahan organik $15 \mathrm{tha}^{-1}$ dan $10 \mathrm{tha}^{-1}$ pada variabel pengamatan panjang akar primer, panjang hipokotil dan panjang 
kecambah normal menghasilkan nilai tertinggi (Tabel 1). Hal ini sejalan dengan hasil penelitian Safitri dkk., (2010) bahwa pemberian pupuk kandang ayam dengan dosis $10 \mathrm{t} \mathrm{tha}{ }^{-1}$ dan $15 \mathrm{t} \mathrm{ha}^{-1}$ lebih banyak memperbaiki sifat fisik, daya aerasi yang menuju ke arah yang lebih baik sehingga menunjang perkembangan akar yang berfungsi untuk menyerap hara yang lebih banyak.

Menurut Workerdan Ruckman dalam Sutopo (1998), benih dengan bobot yang besar memiliki cadangan makanan lebih banyak daripada yang memiliki bobot yang kecil. Bobot kering kecambah normal adalah salah satu variabel yang menjadi acuan dalam uji keserempakan perkecambahan. Menurut Mugnisjah dan Setiawan (2004), keserempakan tumbuh sejumlah benih dipengaruhi oleh kemampuan benih untuk memanfaatkan cadangan makanan sebagai energi untuk tumbuh secara serempak. Bobot kering kecambah normal pada pemberian bahan organik dengan dosis $15 \mathrm{t} \mathrm{ha}^{-1}$ menghasilkan nilai yang tinggi sebelum dilakukan penyimpanan dan setelah dilakukan penyimpanan. Hal ini menunjukkan bahwa pemberian bahan organik dengan dosis $15 \mathrm{t} \mathrm{ha}^{-1}$ mampu meningkatkan cadangan makanan yang lebih banyak didalam benih sehingga saat perkecambahan benih memiliki ketersediaan cadangan makanan yang cukup sebagai energi untuk tumbuh dengan baik. Energi yang cukup dapat meningkatkan keserempakan tumbuh yang baik, terutama dapat meningkatkan bobot kecambah.

Bobot kering kecambah normal pada Varietas Numbu adalah varietas yang memiliki bobot yang besar dibandingkan dengan varietas Wray dan Keller sebelum menjalani periode simpan dan seletah menjalani periode simpan tiga dan lima bulan. Hal ini menunjukkan bahwa benih varietas Numbu memiliki cadangan makanan yang lebih banyak daripada varietas Wray dan Keller, sehingga varietas Numbu memiliki energi yang cukup untuk tumbuh secara serentak dan menghasilkan kecambah yang memiliki bobot yang baik. Hasil penelitian menunjukkan bahwa vigor awal dan viabilitas awal benih varietas Numbu tinggi dan setelah menjalani periode simpan juga tetap tinggi, sehingga dapat dikatakan bahwa mutu fisiologis benih varietas Numbu lebih baik daripada varietas Numbu dan Keller. Hal ini sejalan dengan hasil penelitian Leonard dkk., (2013) yang menyatakan bahwa varietas Numbu memiliki pertumbuan dan hasil produksi yang lebih baik dan lebih respon terhadap perlakuan lingkungan seperti teknik pengolahan tanah dan pemupukan.

Benih yang memiliki sifat genetik yang berbeda namun disimpan dalam wadah dan waktu yang sama, memiliki perbedaan mutu fisiologis. Hal ini dikarenakan sifat benih yang selalu ingin mencapai keseimbangan dengan kondisi lingkungan, padahal kadar air behin sangat mempengaruhi laju deteriorasi benih. Semakin tinggi kadar air semakin tinggi pula laju deteriorasi benih. Hal ini didukung dengan penyerapan air oleh benih dipengaruhi oleh ketebalan kulit benih, struktur dari kulit benih, komposis kimia dari benih dan kulit benih (Kuswanto, 2003).

Hasil penelitian menunjukkan bahwa terdapat interaksi antara pemberian bahan organik dan vaietas pada persentase kecambah normal total setelah dilakukan penyimpanan selama tiga dan lima bulan. Pada interaksi menunjukkan bahwa pemberian bahan organik 10 dan 15 t/ha pada varietas Numbu dan Keller memiliki nilai yang lebih tinggi dari pada pemberian bahan organik $5 \mathrm{t} \mathrm{ha}^{-1}$ (Tabel 3 dan 4), namun interaksi yang terlihat pada panjang akar primer menunjukkan bahwa pemberian bahan organik $15 \mathrm{tha}^{-1}$ pada varietas Numbu memiliki nilai yang tertinggi daripada interaksi yang lainnya (Tabel 5). Hal ini dikarenakan kemampuan tanaman dalam menyerap atau memanfaatkan unsur hara yang telah disediakan oleh tanah. Hara diserap dalam bentuk ion bermuatan positif dan negatif. Tanaman menyerap unsur hara dari dalam tanah dengan jumlah dan perbandingan yang berbeda-beda tergantung jenis atau spesies tanamannya (Rahim dkk., 2005).

\section{KESIMPULAN}

Dari hasil penelitian dapat disimpulkan sebagai berikut : 1) Pemberian dosis bahan organik yang berbeda menghasilkan mutu fisiologis yang berbeda, yang ditunjukkan oleh variabel persentase kecambah normal total, pemberian dosis $15 \mathrm{t} \mathrm{ha}^{-1}$ menghasilkan mutu fisiologis benih sorgum yang lebih tinggi daripada yang tidak diberikan bahan organik (kontrol), sedangkan dengan dosis 5 dan $10 \mathrm{t} \mathrm{ha}^{-1}$, mutu fisiologis benihnya tidak berbeda dengan yang tanpa diberikan bahan organik. 2) Varietas Numbu menghasilkan mutu fisiologis yang lebih tinggi daripada varietas Wray dan Keller, sedangkan varietas Wray menghasilkan mutu fisiologis yang lebih tinggi daripada varietas Keller terutama setelah benih disimpan selama 3 dan 5 bulan yang ditunjukkan oleh variabel persentase kecambah normal total. 3) Pengaruh antara varietas dan dosis bahan organik nyata pada mutu fisiologis benih yang ditunjukkan oleh variabel persentase kecambah normal total dengan kombinasi a) varietas Numbu dengan bahan organik 10 dan $15 \mathrm{t} \mathrm{ha}^{-1}$, b) varietas Keller dengan bahan organik 10 dan $15 \mathrm{t} \mathrm{ha}^{-1}$, c) varietas Wray tanpa bahan organik. 


\section{DAFTAR PUSTAKA}

Devi, W.E, Mudji,S., dan Ninuk, H. 2013. Pengaruh Pemberian berbagai Komposisi Bahan Organik pada pertumbuhan dan Hasil Tanaman Bawang Merah. Jurnal Produksi Tanaman. 1 (3) : 21-39.

FAO, Agricultural Department. 2005. Sweet Sorghum in China. World Food Summit,. http// www.fao.org/ag. Diakses 20 Agustus 2013.

Gardner, F. P. Pearce, R. B., dan Mitchel, R. L. 1991. Physiology of Crop Plant (Fisiologi Tanaman Budidaya, alih Bahasa oleh HerawatiSusilo). Jakarta : University of Indonesia Press. $290 \mathrm{hlm}$.

Kuswanto. 2003. Teknologi Pemerosesan Pengemasan dan Penyimpanan Benih. PT Rineka Cipta. Jakarta. 188 hlm.

Leonard, S M. T, Irmansyah, dan Charani, H. 2013. Respon Pertumbuhan dan Produksi Tiga Varietas Sorgum (Sorghum bicolor [L.] Moench) dengan Perbedaan Sistem Pengolahan Tanah. Jurnal Online Agroekoteknologi USU.2337-2697. 1 (4) :11-22

Mugnisjah, W, Q dan A. Setiawan. 2004. Produksi Benih. Bumi Aksara. Jakarta. 603 hlm.

Pramono, E. 2010. Pengaruh Pupuk Organik dan Pupuk Mikro dapa Produksi dan Mutu Benih Padi (Oryza sativa L). Jurnal Agronomika. 10 (1) : 11-23.

Rahim, Ima, dan Iklima. 2005. Serapan N produksi padi gogo (Oriza Sativa) pada dua sistem olah tanah dan penerapan waktu jangka panjang (musim tanam ke-33) di lahan kering Bandar Lampung. Skripsi. No. Klas 631. 81. Rd. 5.Universitas Lampung. $97 \mathrm{hlm}$.
Rahmawati dan Sania, S. 2010. Mutu Fisiologis benih pada Beberapa Varietas Jagung Selama Periode Simpan. Prosiding Pekan Serelia Nasional. 978979 (3) : 29-40.

Rany, S. Nasrez, A., dan Irfan, S. 2010. Pengaruh Jarak Tanam dan Dosis Pupuk Kandang Ayam terhadap Pertumbuhan dan Hasil Tanaman Sorgum Manis (Sorghum bicolor [L.] Moench). Jurnal Jerami. 3 (2) : 107-119.

Safitri, R, N. Akhir, dan I. Suliansyah. 2010. Pengaruh Jarak Tanam dan Dosis Pupuk Kandang Ayam Terhadap Pertumbuhan Dan Hasil Tanaman Sorgum Manis (Sorghum Bicolor, L. Moench). Jurnal Jerami 3 (2) : 12-23.

Salomao, A. N. 2002. Tropical Seeds Species Responces to Liquid Nitrogen Exposu-re. Braz J. Plant Physiol. 14 (1) : 133-138.

Simanjuntak, Dahlia. 2006. Pemanfaatan Komoditas non Beras dalam Diversifikasi Pangan Sumber Kalori. Jurnal penelitian Bidang Ilmu Pertanian USU. 4 (1) : 45-54.

Soeranto, H. 2008. Perbaikan sifat agronomi dan kualitas sorgum sebagai sumber pangan, pakan ternak, dan bahan industri melalui pemuliaan tanaman dengan teknik mutasi. Prosiding Seminar Nasional Hasil Penelitian. Badan Tenaga Nuklir Nasional (BATAN). Bogor. hlm 226-233.

Suriadikarta, D.A., T. Prihatini, D. Setyorini, dan W. Hartatik. 2005. Teknologi Pengelolaan Bahan Organik Tanah. Dalam Teknologi Pengelolaan Lahan Kering' Puslitbangtanah. Badan Litbang Pertanian. 7 (1): 169-222.

Sutopo. 1998. Teknologi Benih. PT. Raja Grafindo Persada. Jakarta. 182 hlm. 